\title{
Goat dung as a feedstock for hyper-production of amylase from Glutamicibacter arilaitensis strain ALA4
}

\author{
Chirom Aarti, Ameer Khusro and Paul Agastian*
}

\begin{abstract}
Background: In modern times, bacteria-associated products; especially enzymes are gaining immense interest among worldwide researchers. Among several enzymes, amylases are of great significance in bioprocess engineering. This investigation was aimed to optimize the amylase production from Glutamicibacter arilaitensis strain ALA4 using goat dung as an inexpensive substrate in solid-state fermentation.

Results: Amylase production was initially improved by optimizing physical factors and medium components by one factor at a time method. Two-level full factorial design ( $2^{5}$ factorial matrix) was applied to screen the selected variables using first-order polynomial model. Parameters such as incubation temperature, moisture, starch, and yeast extract affected the amylase activity significantly $(P<0.05)$. Central composite design at $N=30$ was further employed to evaluate the optimum levels of these variables by a second-order polynomial equation. Maximal amylase activity of $4572.53 \pm 41.71 \mathrm{U} / \mathrm{g}$ was estimated in the goat dung medium supplemented with $100 \%$ moisture, $1 \%(\mathrm{w} / \mathrm{w})$ starch, and $1 \%(\mathrm{w} / \mathrm{W})$ yeast extract, being incubated at $40^{\circ} \mathrm{C}$. The optimized parameters revealed approximately twofold increment in the amylase yield ( $R^{2}$ 0.9169) with respect to the original medium. The amylase showed stability at high $\mathrm{pH}$ and temperature up to $4 \mathrm{~h}$ of incubation with residual activities of $52.32 \pm 2.2$ and $46.12 \pm 3.3 \%$, respectively. Additionally, the enzyme revealed resistant property not only towards various metal ions and organic solvents but also surfactants and inhibitors. Most importantly, the amylases obtained from strain ALA4 depicted remarkable tolerance to commercially available various detergents.
\end{abstract}

Conclusions: This study reports first reference on the hyper-production of amylase from G. arilaitensis using goat dung as the low-cost agro-waste medium. G. arilaitensis strain ALA4 may be utilized for wide spread applications in several bioprocess industries due to the high stability of its amylase towards diversified $\mathrm{pH}$, temperature, solvents, surfactants, and detergents.

Keywords: Amylases, $2^{5}$ factorial design, solid-state fermentation, Stability, central composite design

\section{Background}

No doubt, amylases represent one of the most important groups of industrial enzymes, and occupy 35\% of global enzyme markets at present (Azad et al. 2009). These enzymes play tremendous role in diversified industries viz. dairy, food processing, chocolates, pharmaceuticals, leather, textiles, paper and pulp, wine, meat,

\footnotetext{
*Correspondence: agastianloyolacollege@gmail.com; agastian@loyolacollege.edu

Research Department of Plant Biology and Biotechnology, Loyola College, Nungambakkam, Chennai, Tamil Nadu 600034, India
}

fish processing, detergents, chemical, and bioenergy. Amylases act on starch or oligosaccharide molecules in a random manner and convert them into dextrins and progressively smaller polymers by hydrolyzing $\alpha$-1,4and $\alpha-1,6$-glycosidic linkages. The starch hydrolyzing enzymes can be derived from several sources such as plants, animals, and microbes. But the exploitation of microorganisms for the production of amylases has gained immense interest among researchers in last few decades. Moreover, bacterial amylases have dominated as bioresources in industries due to their stability at harsh 
conditions, enhanced enzyme activity at optimized variables, rapid growth, easy maintenance, cost-effectiveness and accessibility for genetic manipulations to obtain enzymes of desired characteristics (Khusro et al. 2017). In recent years, amylases have been screened and characterized from novel strains of bacteria including Bacillus cereus (Roohi et al. 2013), Bacillus thuringiensis (Smitha et al. 2013), Aeromonas veroni and Stenotrophomonas maltophilia (Kumar et al. 2014), and Chryseobacterium sp. (Hasan et al. 2017).

The utilization of organic solid wastes for the production of value-added products, particularly enzymes from bacteria in economically developing countries is increasing nowadays. Nevertheless, organic wastes comprised materials rich in sugars, minerals, and proteins that could be used as substrates. Since the cultivation of bacteria requires carbon, nutrient, and moisture, organic waste could be a promising candidate to provide the appropriate environment for the bacterial growth. From these points of view, solid-state fermentation (SSF) is considered as a promising approach for waste valorization through the bioconversion of organic wastes used as either substrate or inert support (Yazid et al. 2017). SSF is a useful technique for the biosynthesis of enzymes and other metabolites in bacteria through the biorefineries of organic solid wastes. The organic wastes such as banana peel (Sajjad and Choudhry 2012), cow dung (Vijayaraghavan et al. 2015), brewery waste (Blanco et al. 2016), and kitchen wastes (Awodun et al. 2007) were recently used as promising substrates for the production of extracellular amylases. In spite of this, the quest of a novel, inexpensive, and easily available substrate for the hyperproduction of amylases from new bacterial sources is a continuous process.

In SSF process, the solid materials are known to provide paramount nutrients for the growth of bacteria. Hence, an ideal solid substrate should contain adequate nutrients to support the bacterial growth and the production of enzymes. Goat dung is a cogent source of ash, carbon, nitrogen, phosphorus, potassium, calcium, magnesium, and other organic dry matter (Awodun et al. 2007), thereby indicating it as an efficacious feedstock for the growth of bacteria, and further production of enzymes from them in a cost-effective manner in several industrialized and developing countries. However, to the best of our knowledge, the report on the utilization of goat dung for the production of amylase from bacterial sources is unexploited and undetermined yet.

The fermentation medium optimization is an imperative step for the enhanced production of industrially important enzymes. The optimization of the fermentation medium by statistical methods is a promising approach to identify the significant variables responsible for the optimum production of enzymes. The statistical tools such as $2^{5}$ full factorial design and central composite design (CCD) of response surface methodology (RSM) are decisive strategies to improve enzyme yield by designing minimum number of experiments for large number of factors. Most importantly, RSM explains the combined effects of selected variables in a fermentation process (Khusro et al. 2016). In last decade, plethoras of researches have been reported for the successful implementation of these statistical tools to enhance the production of industrially important enzymes from distinct microbial sources.

In view of the presence of ample nutritional constituents, easy availability, and cost-effectiveness characteristics, the present context was investigated to determine the unique potency of goat dung as substantial agroresidual waste substrate for the hyper-production of amylase from the new strain of Glutamicibacter arilaitensis. The process variables were further optimized using statistical tools, and the amylase was partially characterized for various industrial purposes.

\section{Methods \\ Sampling and isolation of bacteria}

Industrial waste dumped soil was collected from Ambattur Industrial Estate, Chennai, India. The sample was kept in sterilized polythene bag and brought to the laboratory for immediate processing. One gram of soil was suspended in $9 \mathrm{~mL}$ of sterile distilled water and serially diluted. Hundred microlitres of suspension were spread aseptically on sterilized agar plates (g/L; peptone-10.0; yeast extract-5.0; $\mathrm{KH}_{2} \mathrm{PO}_{4}-1.0 ; \mathrm{MgSO}_{4} \cdot 7 \mathrm{H}_{2} \mathrm{O}-0.2 ; \mathrm{Na}_{2} \mathrm{CO}_{3}-10.0 ; \mathrm{NaCl}-$ 3.0; agar-20.0; and $\mathrm{pH}-7.0$ ). These plates were incubated further at $37^{\circ} \mathrm{C}$ for $24 \mathrm{~h}$ and observed for the development of colonies. After required period of incubation, the morphologically dissimilar colonies were streaked on freshly prepared agar media in order to obtain pure culture. These purified bacterial cultures were maintained in $50 \%(\mathrm{v} / \mathrm{v})$ glycerol at $-80{ }^{\circ} \mathrm{C}$ for further qualitative assay of extracellular amylase production.

\section{Screening of hyperamylase producing bacteria}

All the isolates were grown in the sterilized fermentation medium consisted of: [(\% w/v) peptone-1.0; yeast extract $-0.5 ; \mathrm{KH}_{2} \mathrm{PO}_{4}-0.1 ; \mathrm{MgSO}_{4} \cdot 7 \mathrm{H}_{2} \mathrm{O}-0.02$; $\mathrm{Na}_{2} \mathrm{CO}_{3}-1.0 ; \mathrm{NaCl}-0.3$; starch-1.0, agar-2.0; and $\mathrm{pH}-7.0]$, and incubated at $37^{\circ} \mathrm{C}$ for $24 \mathrm{~h}$ with an agitation speed of $130 \mathrm{rpm}$. After $24 \mathrm{~h}$ of incubation, all the cultures were centrifuged at $8000 \mathrm{~g}$ for $15 \mathrm{~min}$ and supernatants were collected for qualitative assay. On the other hand, starch agar media (g/L: starch-10.0, agar-20.0 and $\mathrm{pH}-7.0$ ) were prepared and wells were made using cork borer. The collected supernatants were poured into the respective well of each plate and incubated 
further at $37^{\circ} \mathrm{C}$ for $24 \mathrm{~h}$. After the incubation period, the starch agar plates were flooded with iodine solution and observed for the largest halo zone of starch hydrolysis. The potent bacterium with hyperamylase producing ability was selected for further experimental purposes. This selected strain was subjected to morphological, biochemical and molecular characterization studies.

\section{Molecular characterization}

Genomic DNA of bacteria was isolated and the amplicon was obtained using the thermal cycler (Eppendorf Gradient, Chennai, India) and universal primers. The amplicon was purified and the sequencing of 16S rRNA was done using an automated sequencer (Genetic Analyzer 3130, Applied Biosystems, Foster city, CA, USA). Further, the similarity search of the sequence was carried out using the NCBI, BLAST and the sequences were submitted to GenBank.

\section{Substrates used}

The agro-wastes viz. banana peel, paddy straw, wheat bran, rice bran, corn cob, rice flour, and sugarcane bagasse were collected from local market of Nungambakkam, Chennai, India, and dried for 7-10 days at room temperature. On the other hand, goat dung was collected locally and dried for 7-10 days in sunlight. These dried agro-wastes were powdered using a mixer grinder, sieved and stored in screw capped bottle for further process.

\section{Solid-state fermentation}

Ten grams of the solid substrates (banana peel, paddy straw, goat dung, wheat bran, rice bran, corn cob, rice flour, and sugarcane bagasse) were taken separately in $250 \mathrm{~mL}$ Erlenmeyer flasks and the moisture content was maintained as $100 \%$ using tris- $\mathrm{HCl}$ buffer $(\mathrm{pH}$ 8.0, $0.1 \mathrm{M}$ ). The contents were mixed and sterilized at $121{ }^{\circ} \mathrm{C}$ for $15 \mathrm{~min}$. After cooling the flasks, $5 \%$ bacterial inoculum $\left(\mathrm{OD}_{600 \mathrm{~nm}}=1.12\right)$ was inoculated aseptically and incubated at $37{ }^{\circ} \mathrm{C}$ for $48 \mathrm{~h}$ under static conditions. After required period of incubation, $50 \mathrm{~mL}$ of sterilized distilled water was added to the fermented substrate, and further incubated in an orbital shaker at $150 \mathrm{rpm}$ for $30 \mathrm{~min}$ to extract the enzyme. The mixture was filtered, and cultures were further centrifuged at $8000 \mathrm{~g}$ for $15 \mathrm{~min}$. The clear supernatant obtained was used as the source for crude amylase.

\section{Quantitative assay for amylase}

Amylase activity was assayed according to the methodology of Miller (1959) with slight modifications. The supernatant of $48 \mathrm{~h}$ grown bacterial culture under SSF was used as crude amylase. One milliliter of supernatant was mixed with $1 \mathrm{~mL}$ of solubilized starch solution $(1 \%$ $\mathrm{w} / \mathrm{v}$ ) and the reaction mixture was incubated at $60^{\circ} \mathrm{C}$ for
$10 \mathrm{~min}$. The reaction was stopped by adding $1 \mathrm{~mL}$ of dinitrosalicylic acid (DNS) into it and the solution was later incubated at $100{ }^{\circ} \mathrm{C}$ for $5 \mathrm{~min}$. The solution was allowed to cool and further centrifuged at $8000 \mathrm{~g}$ for $10 \mathrm{~min}$. The absorbance of the supernatant was read at $540 \mathrm{~nm}$. One unit of amylase activity was estimated as the amount of enzyme releasing $1 \mu \mathrm{g}$ of reducing sugar as maltose per minute, under specific assay conditions. Total extracellular protein content was estimated using bovine serum albumin as standard (Bradford 1976).

\section{Optimization of amylase production by one-factor-at-a-time approach}

One-factor-at-a-time (OFAT) based approach was initially implemented to screen the influence of various process parameters on amylase production from the isolate. Ten grams of goat dung was moistened with $10 \mathrm{~mL}$ of tris- $\mathrm{HCl}$ buffer ( $\mathrm{pH}$ 8.0, $0.1 \mathrm{M}$ ) in $250 \mathrm{~mL}$ Erlenmeyer flask. The diverse culture conditions viz. incubation period (12-96 h), $\mathrm{pH}(6.0-11.0)$, temperature $\left(32-60^{\circ} \mathrm{C}\right)$, inoculum (7.31-54.82 $\log \mathrm{CFU} / \mathrm{mL})$, moisture content (60-120\%), and medium components such as carbon sources $(1 \% \mathrm{w} / \mathrm{w}$-glucose, sucrose, maltose, starch, xylose, mannose and lactose) and nitrogen sources $(0.5 \%$ $\mathrm{w} / \mathrm{w}-$ peptone, casein, yeast extract, beef extract, tryptone, potassium nitrate, ammonium sulphate and ammonium chloride) were taken into consideration to optimize and enhance the amylase yield from the bacteria. SSF and amylase assay were carried out as described earlier.

\section{Full factorial matrix}

Two-level full factorial design was applied to optimize five selected variables $(\mathrm{pH}$, temperature, moisture content, starch and yeast extract) to achieve enhanced production of amylase from the isolate. Other parameters such as incubation period and inoculum level were maintained at their middle levels. These selected variables were tested at two levels, high $(+)$ and low $(-)$ during a total of 32 experimental runs. Experiments were carried out using goat dung as substrate under SSF for $48 \mathrm{~h}$ with $18.27 \log \mathrm{CFU} / \mathrm{mL}$ of bacterial culture. The statistical parameters were evaluated using analysis of variance (ANOVA), and $P<0.05$ was considered as significant. The impact of variables on the response was calculated using first-order polynomial model:

$$
\begin{aligned}
Y=\alpha_{0} & +\sum_{i} \alpha_{i} x_{i}+\sum_{i j} \alpha_{i j} x_{i} x_{j} \\
& +\sum_{i j k} \alpha_{i j k} x_{i} x_{j} x_{k}+\sum_{i j k l} \alpha_{i j k l} x_{i} x_{j} x_{k} x_{l} \\
& +\sum_{i j k l m} \alpha_{i j k l m} x_{i} x_{j} x_{k} x_{l} x_{m}
\end{aligned}
$$


where $Y$ is the response (amylase activity), $\alpha_{0}$ is the intercept, $\alpha_{i}$ is the $i$ th linear coefficient, $\alpha_{i j}, \alpha_{i j k}, \alpha_{i j k l}$ and $\alpha_{i j k l m}$ are the interaction coefficients.

The goodness of fit of the first-order polynomial equation was expressed by coefficient of determination $\left(R^{2}\right)$ and its statistical significance level was checked by $F$ test, keeping desirability at maximum.

\section{Response surface methodology}

Response surface methodology (RSM) was implemented to optimize the culture conditions and medium components that significantly affected the amylase yield after two-level factorial matrix. The influencing factors viz. temperature, moisture, starch and yeast extracts were optimized further for enhancing extracellular amylase yield of the strain using central composite design (CCD). Each variable in the design matrix was employed at five different levels $(-\alpha,-1,0,+1,+\alpha)$. The five coded levels of alpha, studied in the present study were $-2,-1$, $0,+1$ and +2 . According to the present experimental design, the total number of treatment combinations is $2^{k}+2 k+n$, where ' $k$ ' is the number of variables and ' $n$ ' is the number of repetition of experiments at the central point. The experimental plan of independent variables with respect to their values in actual and coded form is shown in Table 2. The effects of selected factors to the response were estimated by a second-order polynomial equation:

$$
\begin{aligned}
Y=\beta_{0} & +\beta_{1} A+\beta_{2} B+\beta_{3} C+\beta_{4} D+\beta_{11} A^{2} \\
& +\beta_{22} B^{2}+\beta_{33} C^{2}+\beta_{44} D^{2}+\beta_{12} A B \\
& +\beta_{13} A C+\beta_{14} A D+\beta_{23} B C \\
& +\beta_{24} B D+\beta_{34} C D
\end{aligned}
$$

where $Y=$ response variable (amylase activity), $\beta_{0}=$ intercept, $\beta_{1}, \beta_{2}, \beta_{3}$ and $\beta_{4}=$ linear coefficients, $\beta_{11}, \beta_{22}, \beta_{33}$ and $\beta_{44}=$ squared coefficients, $\beta_{12}, \beta_{13}, \beta_{14}, \beta_{23}, \beta_{24}$, and $\beta_{34}=$ interaction coefficients, $A, B, C, D, A^{2}, B^{2}, C^{2}, D^{2}, A B$, $A C, A D, B C, B D$ and $C D=$ levels of independent variables.

The $3 \mathrm{D}$ response plot was used to understand the interrelationship among diversified factors and to predict optimum ranges responsible for the enhanced production of amylase.

\section{Validation of design}

The validation of the experimental design for amylase production was conferred under SSF by carrying out the experiments based on the optimum values of variables selected using CCD. The experiments were carried out in triplicate and the enzyme activity of the isolate was estimated according to the methodology as described earlier, and then compared with the predicted values of amylase yield.

\section{Partial characterization of amylase}

The crude amylase obtained from the isolate under optimized culture conditions and medium components of $\mathrm{CCD}$ was used for the characterization studies. The stability of amylase at diversified $\mathrm{pHs}(\mathrm{pH}$ 6.0-11.0) was evaluated using sodium phosphate $(0.1 \mathrm{M} ; \mathrm{pH} 6.0-7.0)$, tris $-\mathrm{HCl}$ (0.1 M; pH 8.0-9.0), carbonate-bicarbonate $(0.1 \mathrm{M} ; \mathrm{pH}$ $10.0)$, and glycine- $\mathrm{NaOH}(0.1 \mathrm{M} ; \mathrm{pH} 11.0)$ buffer solution under standard assay conditions. To check the stability of amylase at varied $\mathrm{pH}, 100 \mu \mathrm{L}$ of enzyme solution was mixed with $900 \mu \mathrm{L}$ of above mentioned respective buffer solution and incubated up to $4 \mathrm{~h}$. The residual activity of enzyme at $1 \mathrm{~h}$ interval was determined as described earlier. To evaluate the temperature stability of amylase, the enzyme solution was subjected to denaturation at diverse temperatures ranging from 35 to $85^{\circ} \mathrm{C}$ up to $4 \mathrm{~h}$ of incubation, and the residual activity of the enzyme was estimated. To investigate the impact of ions on amylase stability, the enzyme solution was preincubated with different divalent metal ions $(10 \mathrm{mM})$ viz. $\mathrm{Mg}^{2+}, \mathrm{Ca}^{2+}, \mathrm{Hg}^{2+}, \mathrm{Zn}^{2+}, \mathrm{Cu}^{2+}$, $\mathrm{Fe}^{2+}, \mathrm{Mn}^{2+}$, and $\mathrm{Co}^{2+}$ at optimum temperature, and the residual activity of amylase was estimated against the control (enzyme solution devoid of ions) under standard assay conditions after $4 \mathrm{~h}$ of incubation.

\section{Eco-friendly applications of amylase}

The thermo-alkali and metal ions stable amylase obtained from the isolate was further evaluated for its stability towards various organic solvents, surfactants, inhibitors, and detergents. The enzyme solution was initially filtered using nitrocellulose membrane $(0.2 \mu \mathrm{m})$, and then incubated with $40 \%(\mathrm{v} / \mathrm{v})$ of varied polar and non-polar organic solvents viz. $n$-hexane, $n$-butanol, benzene, toluene, ethanol, methanol, ethyl acetate, chloroform, acetone, and propanol for 7 days in screw crapped tubes. After required period of incubation, the residual activity of amylase was estimated against the control (enzyme solution without addition of organic solvents) according to the methodology as described earlier. In addition to this, the stability of amylase was determined in the presence of various surfactants (1\%; Tween 20, Tween 40, Tween 60, Tween 80, and SDS), inhibitors (1 mM; EDTA, hydrogen peroxide, and mercaptoethanol), and detergents (1\%; Tide, ARIEL, Surf excel, POWER, Wheel, Nirma, and RIN). The detergent solution was initially boiled for $15-20 \mathrm{~min}$ to denature or inactivate the existing enzymes that could be incorporated during their formulation. The amylase was then incubated with these detergent solutions, and the reaction mixture was incubated for $24 \mathrm{~h}$. The residual activities of amylase were estimated against the control (enzyme solution devoid of surfactants, inhibitors, and detergents) under standard assay conditions as described earlier. 


\section{Statistical analyses}

All variables were optimized and interpreted using Design Expert Version 10.0.0 (Stat-Ease Inc., Minneapolis, Minnesota, USA) statistical software. ANOVA was used to validate statistical parameters. The values " $P<0.05$ " were considered statistically significant. All the experiments were carried out in triplicate and data were expressed as mean $\pm \mathrm{SD}$.

\section{Results}

\section{Screening and identification of hyperamylase producing} bacteria

Of 56 morphologically dissimilar purified bacterial isolates, 30 isolates were identified as extracellular amylase producing bacteria. Among 30 isolates, one potent bacterium was selected based on its hyper amylolytic zone on starch agar plate (figure not shown). The colony of the selected isolate was round, opaque, and white in colour. Microscopically, the bacterium was rod-shaped. Further, the isolate was identified as catalase and protease positive. The isolate had potentiality to ferment various saccharides viz. glucose, sucrose, arabinose, mannitol and trehalose. The isolate showed negative results towards Malonate, Indole, Voges-proskauer, Citrate utilization, ONPG, Nitrate reductase and Arginine. The isolate was identified as G. arilaitensis strain ALA4 based on $16 \mathrm{~S}$ rRNA gene sequencing (1238 bp; Accession Number KY795955).

\section{Solid-state fermentation using various agro-residues}

Glutamicibacter arilaitensis strain ALA4 utilized all the agro-residues for the growth and subsequent production of extracellular amylase. The enzyme yield was observed to be varied with the type of substrate implemented under SSF. The study revealed that maximum production of amylase $(1723.65 \pm 32.3 \mathrm{U} / \mathrm{g})$ was obtained using goat dung as substrate. On the other hand, amylase production was observed to be in the order of $1386.25 \pm 28.2$ $>1302.28 \pm 34.9>1121.23 \pm 26.3>973.45 \pm 31.6>862$. $45 \pm 33.4>765.35 \pm 25.3>585.23 \pm 23.2 \mathrm{U} / \mathrm{g}$, for paddy straw, wheat bran, rice bran, sugarcane bagasse, corn cob, banana peel, and rice flour, respectively (Fig. 1).

\section{Optimization of amylase production by OFAT method}

The influence of incubation period on amylase yield from strain ALA4 is shown in Fig. 2a. The amylase activity was found to be increased linearly with increase in the incubation time up to $48 \mathrm{~h}(1790.32 \pm 31.3 \mathrm{U} / \mathrm{g})$, and decreased thereafter. $\mathrm{pH}$ of the fermentation medium ranging from 6 to 11 showed profound impact on the amylase activity. The amylase activity gradually increased with increase in the $\mathrm{pH}$ of the fermentation medium, being the maximum at $\mathrm{pH} 8(1923.45 \pm 32.3 \mathrm{U} / \mathrm{g})$. Further increase in $\mathrm{pH}$ depicted the significant reduction in the amylase activity (Fig. 2b). Figure 2c shows the effect of varied incubation temperature on the amylase activity of strain ALA4. The optimum temperature for the amylase production from the isolate was observed to be at $42{ }^{\circ} \mathrm{C}(2042.14 \pm 25.9 \mathrm{U} / \mathrm{g})$. There was a gradual reduction in the amylase activity of strain ALA4 at higher incubation temperature, being the lowest at $60{ }^{\circ} \mathrm{C}(732.12 \pm 23.3 \mathrm{U} / \mathrm{g})$. There was not much variation observed in the amylase yield at different inoculum of strain ALA4 (Fig. 2d). Maximum amylase activity of $2012.14 \pm 23.3 \mathrm{U} / \mathrm{g}$ was observed at 18.27 $\log \mathrm{CFU} / \mathrm{mL}$ of bacterial culture. The amylase yield of $1412.21 \pm 24.2,1998.14 \pm 30.2$, and $1802.12 \pm 31.3 \mathrm{U} / \mathrm{g}$ was observed at 7.31, 36.55, and $54.82 \log \mathrm{CFU} / \mathrm{mL}$ of

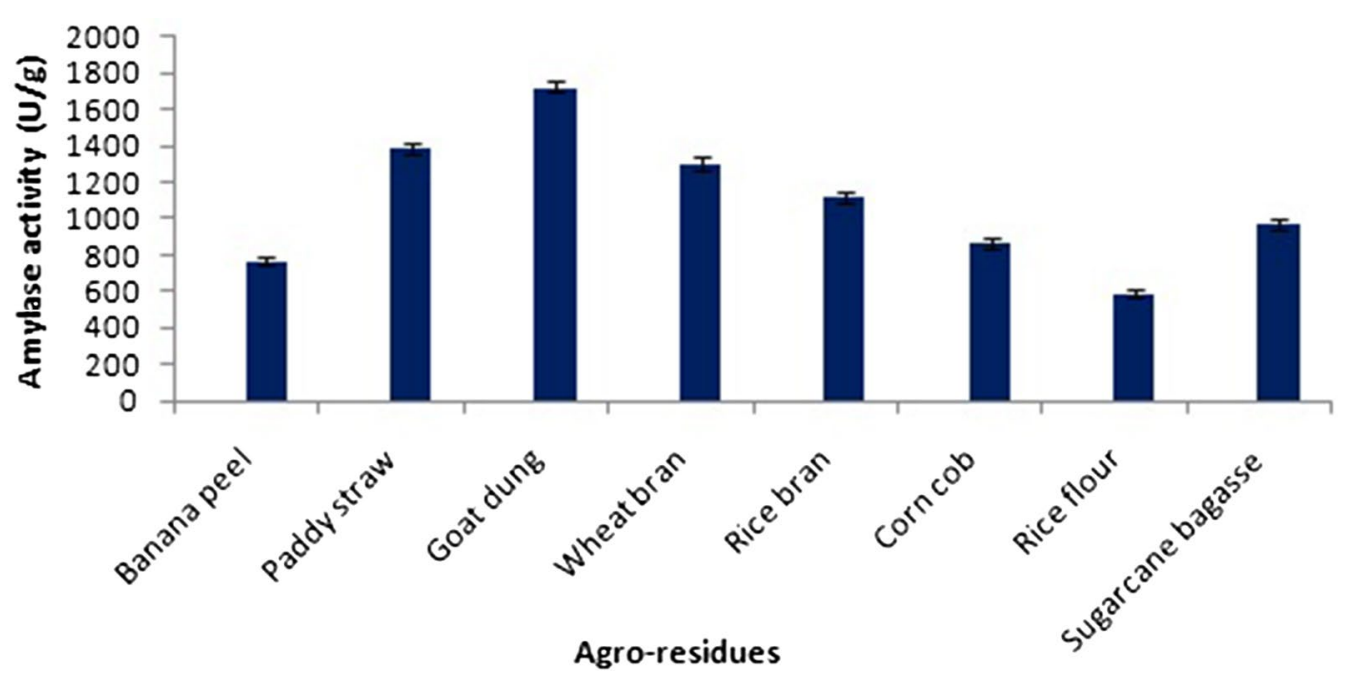

Fig. 1 Amylase activity of strain ALA4 in the presence of various agro-residues. Values represent mean $\pm S D$ 

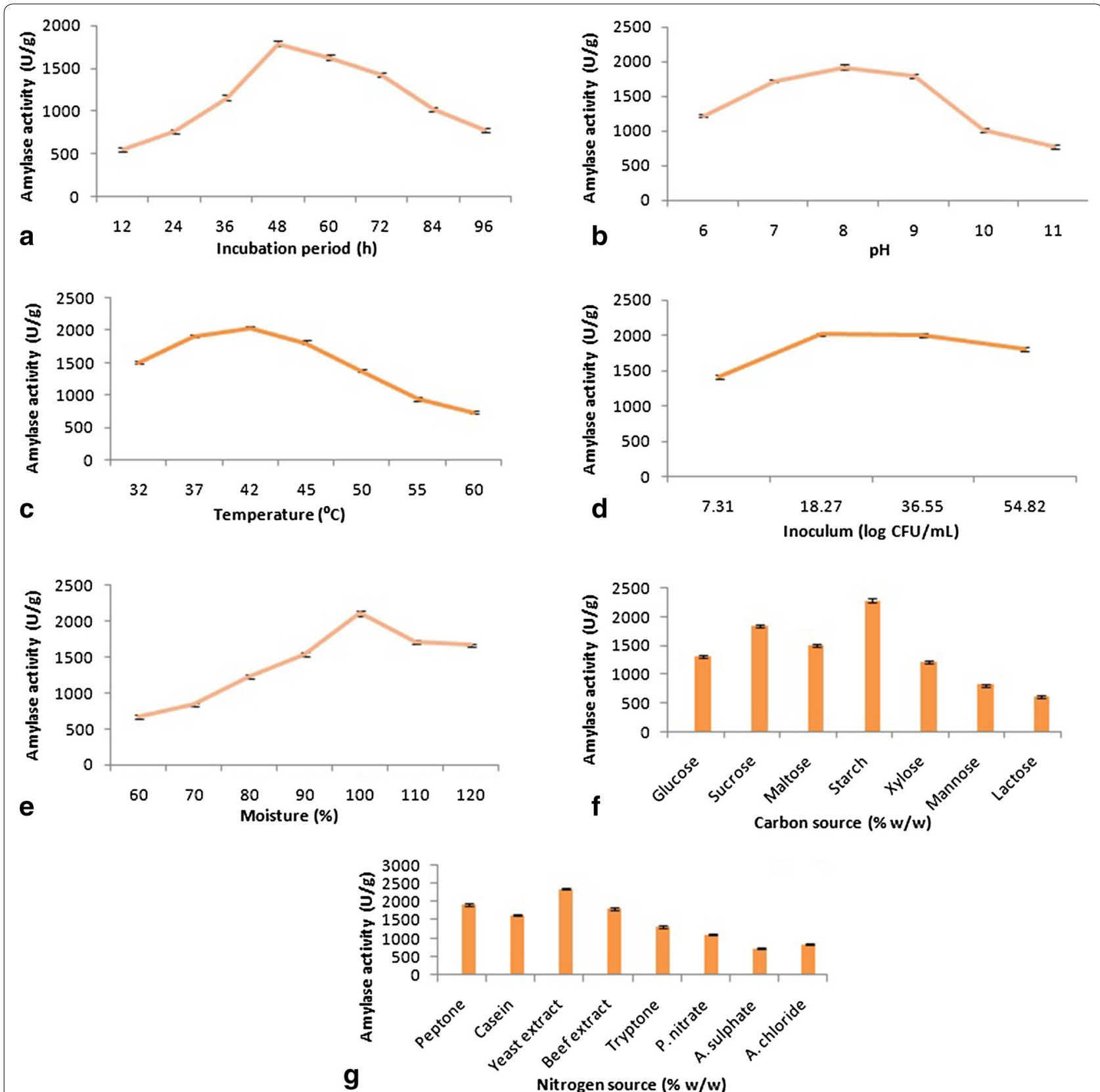

Fig. 2 Effect of a incubation period; $\mathbf{b}$ pH; c temperature; $\mathbf{d}$ inoculum level; e moisture content; $\mathbf{f}$ carbon sources; and $\mathbf{g}$ nitrogen sources on extracellular amylase production from strain ALA4. Values represent mean \pm SD

strain ALA4, respectively. The maximum amylase activity of $2108.23 \pm 33.3 \mathrm{U} / \mathrm{g}$ was observed with $100 \%$ moisture content. The enzyme production was found to be affected significantly at lower and higher moisture levels, thereby estimating activity of $665.34 \pm 28.3,834.12 \pm 26.2$, $1223.12 \pm 30.3,1534.23 \pm 31.2,1712.23 \pm 25.4$, and $1668.14 \pm 21.2 \mathrm{U} / \mathrm{g}$ with moisture levels of $60,70,80,90$, 110 , and $120 \%$, respectively (Fig. 2e).
Among the diversified carbon sources tested, starch was found to be the most potent inducer of amylase activity $(2293.34 \pm 30.3 \mathrm{U} / \mathrm{g})$ from strain ALA4, while relatively lower amylase yield ranging from $612.12 \pm 18.3$ to $1834.23 \pm 23.2 \mathrm{U} / \mathrm{g}$ was observed with other carbon sources used such as lactose, mannose, xylose, glucose, maltose, and sucrose (Fig. 2f). The supplementation of various organic and inorganic nitrogen sources into the 
fermentation medium showed that strain ALA4 had potentiality to grow and produce amylase in the presence of tested nitrogen sources (Fig. 2g). Maximum amylase activity of $2367.12 \pm 31.3 \mathrm{U} / \mathrm{g}$ was observed in the culture medium supplemented with yeast extract, followed by peptone $(1932.12 \pm 27.3 \mathrm{U} / \mathrm{g})$, beef extract $(1816.12 \pm 30.2 \mathrm{U} / \mathrm{g})$, casein $(1632.12 \pm 25.2 \mathrm{U} / \mathrm{g})$, tryptone $(1312.14 \pm 28.3 \mathrm{U} / \mathrm{g})$, potassium nitrate $(1112.14 \pm 24.4 \mathrm{U} / \mathrm{g})$, ammonium chloride $(842.14 \pm 18.6 \mathrm{U} / \mathrm{g})$, and ammonium sulphate (732.14 $\pm 18.2 \mathrm{U} / \mathrm{g})$.

\section{Optimization of variables by $2^{5}$ full factorial design}

In the present context, five variables viz. $\mathrm{pH}$, temperature, moisture content, starch, and yeast extract were selected further for enhancing the amylase yield by twolevel full factorial design based on the preliminary amylase activity results obtained through OFAT approach. The selected variables and their respective ranges are shown in Table 1.

Table 2 describes the experimental design as well as amylase activity for 32 runs. The amylase activity in $2^{5}$ full factorial design varied substantially ranging from $1512.34 \pm 48.3$ to $3023.12 \pm 42.14 \mathrm{U} / \mathrm{g}$, and showed more or less equivalent values in a comparison with predicted response. The amylase activity was observed to be enhanced when the medium containing goat dung was supplemented with $0.5 \%(\mathrm{w} / \mathrm{w})$ starch, $0.5 \%(\mathrm{w} / \mathrm{w})$ yeast extract, and maintained at $\mathrm{pH} 7.0$, temperature $37{ }^{\circ} \mathrm{C}$, with $100 \%$ moisture content under SSF. ANOVA was determined to validate the model, and the results have been incorporated in Table 3. The model $F$-value of 20.82 implies the model is significant. Values of "Prob $>F "<0.05$ indicate model terms are significant. In this case temperature $(B)$, moisture $(C)$, starch $(D)$, and yeast extract $(E)$ were observed to be statistically significant $(P<0.05)$. Similarly, the interactive variables viz. $A B, A C, A D, B C, C E, A B C, A B D, A B E, A C E$, and $A B C E$ were proved to be significant model terms. The $R^{2}$ value (0.9706) of this model was close to the Adj- $R^{2}$ value (0.9240). The Pred $R^{2}$ of 0.7907 is in reasonable agreement with the Adj $R^{2}$ value. "Adeq Precision" measures

Table 1 Selected variables and their levels for $2^{5}$ factorial design

\begin{tabular}{lllll}
\hline Variables & Code & Units & \multicolumn{2}{c}{ Range and levels } \\
\cline { 3 - 5 } & & & $\mathbf{- 1}$ & $\mathbf{+ 1}$ \\
\hline $\mathrm{A}$ & $\mathrm{pH}$ & - & 7.0 & 8.0 \\
$\mathrm{~B}$ & Temperature & ${ }^{\circ} \mathrm{C}$ & 37 & 42 \\
$\mathrm{C}$ & Moisture & $\%$ & 90 & 100 \\
$\mathrm{D}$ & Starch & $\%$ & 0.5 & 1 \\
$\mathrm{E}$ & Yeast extract & $\%$ & 0.1 & 0.5 \\
\hline
\end{tabular}

the signal to noise ratio. A ratio greater than 4 is desirable. In the present model, a ratio of 24.085 indicates an adequate signal. Thus, this model can be used to navigate the design space. The model equation for the amylase activity can be written as given below-

$$
\begin{aligned}
& \text { Amylase activity }(Y) \\
& \begin{aligned}
= & 2161.17-13.31 A+44.9 B+75.33 C-44.32 D \\
& +85.79 E+38.03 A B-84.67 A C+53.46 A D \\
& +23.96 A E-111.68 B C+6.99 B D-12.57 B E \\
& +55.3 C E+83.92 A B C-89.5 A B D \\
& +71.17 A B E-36.27 A C E-10.34 B C E+76.94 A B C E
\end{aligned}
\end{aligned}
$$

The variables significantly influencing the amylase activity were further optimized using $C C D$, keeping $\mathrm{pH}$ at middle level.

\section{Response surface methodology}

Table 4 represents the four variables with their respective low, middle and high ranges used in CCD optimization strategy. The CCD matrix of these factors in coded units along with experimental and predicted values of response is given in Table 5.

The amylase activity $(Y)$ optimized through CCD was calculated by the following model equation:

$$
\begin{aligned}
Y(\mathrm{U} / \mathrm{g})= & 3643.23-110.83 A-32.27 B-39.0 C \\
& +185.79 D-86.4 A B-38.99 A C \\
& -328.11 A D+100.93 B C \\
& -72.88 B D+88.07 C D
\end{aligned}
$$

The maximum amylase activity of $4572.53 \pm 41.71 \mathrm{U} / \mathrm{g}$ was obtained from Run No. 12, which consisted of media supplemented with $1 \%(\mathrm{w} / \mathrm{w})$ starch, $1 \%(\mathrm{w} / \mathrm{w})$ yeast extract, and $100 \%$ moisture, in addition to being incubated at $40{ }^{\circ} \mathrm{C}$. The amylase yield from strain ALA4 obtained through CCD, was enhanced about twofold in a comparison with OFAT method, and found to be very much close to the predicted response.

ANOVA for amylase quadric model is provided in Table 6. The model $F$-value of 20.97 implies the model is significant. There is only $0.01 \%$ chance that a large "Model $F$-value" could occur due to noise. Values of "Prob $>F^{\text {" }}$ $<0.05$ indicate model terms are significant. In this case $A$, $D, A B, A D, B C, B D$, and $C D$ are significant model terms. The "Lack of Fit $F$-value" of 2.06 implies the Lack of Fit is not significant relative to the pure error. Non-significant lack of fit is good for the model to fit. The $R^{2}(0.9160)$ denotes better correlation between observed and predicted response values, and indicates the model accurate. In the present context, a low CV (3.67\%) denotes that the experiments performed are highly reliable and precise. 
Table 2 Screening of factors for amylase production from strain ALA4 by two-level factorial design

\begin{tabular}{|c|c|c|c|c|c|c|c|}
\hline \multirow[t]{2}{*}{ Run order } & \multirow[t]{2}{*}{$\mathrm{pH}(A)$} & \multirow[t]{2}{*}{ Temperature $(B)$} & \multirow[t]{2}{*}{ Moisture $(C)$} & \multirow[t]{2}{*}{ Starch $(D)$} & \multirow[t]{2}{*}{ Yeast extract $(E)$} & \multicolumn{2}{|c|}{ Amylase activity (U/g) } \\
\hline & & & & & & Experimental & Predicted \\
\hline 1 & 8 & 37 & 90 & 1 & 0.1 & 1983.34 & 2039.43 \\
\hline 2 & 7 & 37 & 90 & 1 & 0.1 & 1723.45 & 1651.02 \\
\hline 3 & 8 & 37 & 90 & 0.5 & 0.5 & 2012.14 & 2053.55 \\
\hline 4 & 8 & 42 & 100 & 0.5 & 0.5 & 2534.21 & 2521.03 \\
\hline 5 & 7 & 37 & 100 & 0.5 & 0.1 & 2412.13 & 2393.05 \\
\hline 6 & 8 & 42 & 90 & 1 & 0.1 & 2156.14 & 2111.78 \\
\hline 7 & 7 & 37 & 100 & 1 & 0.5 & 2672.12 & 2653.35 \\
\hline 8 & 7 & 37 & 90 & 1 & 0.5 & 1512.34 & 1584.46 \\
\hline 9 & 7 & 42 & 100 & 0.5 & 0.1 & 2112.23 & 2164.67 \\
\hline 10 & 8 & 37 & 100 & 1 & 0.1 & 2145.12 & 2171.43 \\
\hline 11 & 7 & 42 & 100 & 1 & 0.5 & 2042.12 & 2126.83 \\
\hline 12 & 8 & 42 & 100 & 0.5 & 0.1 & 2012.13 & 2013.10 \\
\hline 13 & 7 & 42 & 100 & 1 & 0.1 & 2214.51 & 2162.07 \\
\hline 14 & 7 & 37 & 90 & 0.5 & 0.1 & 1967.12 & 2039.55 \\
\hline 15 & 8 & 42 & 90 & 0.5 & 0.1 & 2214.14 & 2258.50 \\
\hline 16 & 7 & 42 & 100 & 0.5 & 0.5 & 2224.14 & 2129.43 \\
\hline 17 & 7 & 37 & 90 & 0.5 & 0.5 & 2045.12 & 1973.00 \\
\hline 18 & 7 & 42 & 90 & 0.5 & 0.5 & 2136.34 & 2192.04 \\
\hline 19 & 8 & 42 & 90 & 1 & 0.5 & 2245.12 & 2277.26 \\
\hline 20 & 8 & 37 & 90 & 0.5 & 0.1 & 1912.23 & 1856.14 \\
\hline 21 & 7 & 42 & 90 & 1 & 0.5 & 2245.14 & 2189.44 \\
\hline 22 & 8 & 37 & 90 & 1 & 0.5 & 2278.26 & 2236.85 \\
\hline 23 & 8 & 42 & 90 & 0.5 & 0.5 & 2456.12 & 2423.98 \\
\hline 24 & 7 & 42 & 90 & 0.5 & 0.1 & 2267.86 & 2244.44 \\
\hline 25 & 8 & 37 & 100 & 1 & 0.5 & 2219.56 & 2178.56 \\
\hline 26 & 7 & 37 & 100 & 0.5 & 0.5 & 3023.12 & 3041.89 \\
\hline 27 & 7 & 42 & 90 & 1 & 0.1 & 2218.43 & 2241.85 \\
\hline 28 & 8 & 42 & 100 & 1 & 0.1 & 1867.34 & 1866.37 \\
\hline 29 & 7 & 37 & 100 & 1 & 0.1 & 1985.43 & 2004.51 \\
\hline 30 & 8 & 42 & 100 & 1 & 0.5 & 2361.12 & 2374.31 \\
\hline 31 & 8 & 37 & 100 & 0.5 & 0.5 & 1954.27 & 1995.27 \\
\hline 32 & 8 & 37 & 100 & 0.5 & 0.1 & 2014.45 & 1988.14 \\
\hline
\end{tabular}

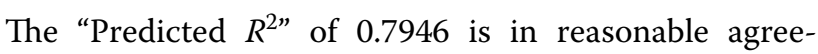

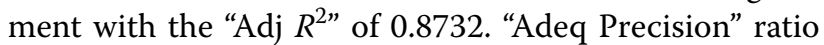
of $18.572(>4)$ indicates an adequate signal and suggests to navigate the design space. Further, the distribution of experimental and predicted values for amylase activity was demonstrated by Parity plot where data points were localized close to the diagonal line, suggesting that the model was accurate and satisfactory (figure not shown).

Figure 3a-f depicts three-dimensional (3D) interaction between variables optimized through CCD for enhanced response. Figure 3 a shows the response graph of interaction between temperature $(A)$ and moisture $(B)$. The 3D plot clearly illustrates that the response was influenced at lower level of temperature $\left(40{ }^{\circ} \mathrm{C}\right)$, and middle level of moisture
(100\%). The interaction between temperature and starch concentration $(C)$ on amylase activity is shown in Fig. $3 \mathrm{~b}$. The response was influenced at lower level of temperature $\left(40^{\circ} \mathrm{C}\right)$, and middle level of starch concentration $(1 \%$ $\mathrm{w} / \mathrm{w})$. Figure $3 \mathrm{c}$ illustrates the interdependent interaction between temperature and varied yeast extract concentrations $(D)$. The amylase activity was found to be increased significantly at lower level of incubation temperature $\left(40^{\circ} \mathrm{C}\right)$, and higher level of yeast extract concentration $(1 \%$ $\mathrm{w} / \mathrm{w})$. The effect of varied moisture and starch concentration is shown in Fig. 3d. Both the variables at their respective middle levels showed enhancement in amylase yield. Figure 3e illustrates that the amylase activity was influenced at middle level of moisture (100\%), and higher level of yeast 
Table 3 Analysis of variance (ANOVA) for amylase yield by $2^{5}$ factorial design

\begin{tabular}{|c|c|c|c|c|c|}
\hline Source & $\begin{array}{l}\text { Sum } \\
\text { of squares }\end{array}$ & $d f$ & Mean square & $F$ value & $\begin{array}{l}P \text { value } \\
\text { prob }>F\end{array}$ \\
\hline Model & $2.318 \mathrm{E}+006$ & 19 & $1.220 E+005$ & 20.82 & $<0.0001$ \\
\hline$A-A$ & 5668.73 & 1 & 5668.73 & 0.97 & 0.3447 \\
\hline$B-B$ & $64,520.40$ & 1 & $64,520.40$ & 11.01 & 0.0061 \\
\hline$C-C$ & $1.816 \mathrm{E}+005$ & 1 & $1.816 \mathrm{E}+005$ & 31.00 & 0.0001 \\
\hline$D-D$ & $62,853.74$ & 1 & $62,853.74$ & 10.73 & 0.0066 \\
\hline$E-E$ & $2.355 E+005$ & 1 & $2.355 E+005$ & 40.20 & $<0.0001$ \\
\hline$A B$ & $46,284.79$ & 1 & $46,284.79$ & 7.90 & 0.0157 \\
\hline$A C$ & $2.294 E+005$ & 1 & $2.294 E+005$ & 39.15 & $<0.0001$ \\
\hline$A D$ & $91,466.85$ & 1 & $91,466.85$ & 15.61 & 0.0019 \\
\hline$A E$ & $18,366.30$ & 1 & $18,366.30$ & 3.13 & 0.1020 \\
\hline$B C$ & $3.991 \mathrm{E}+005$ & 1 & $3.991 \mathrm{E}+005$ & 68.12 & $<0.0001$ \\
\hline$B D$ & 1563.94 & 1 & 1563.94 & 0.27 & 0.6148 \\
\hline$B E$ & 5053.39 & 1 & 5053.39 & 0.86 & 0.3713 \\
\hline$C E$ & $97,842.29$ & 1 & $97,842.29$ & 16.70 & 0.0015 \\
\hline$A B C$ & $2.254 \mathrm{E}+005$ & 1 & $2.254 E+005$ & 38.47 & $<0.0001$ \\
\hline$A B D$ & $2.563 E+005$ & 1 & $2.563 E+005$ & 43.75 & $<0.0001$ \\
\hline$A B E$ & $1.621 \mathrm{E}+005$ & 1 & $1.621 \mathrm{E}+005$ & 27.67 & 0.0002 \\
\hline$A C E$ & $42,107.29$ & 1 & $42,107.29$ & 7.19 & 0.0200 \\
\hline$B C E$ & 3423.57 & 1 & 3423.57 & 0.58 & 0.4594 \\
\hline$A B C E$ & $1.894 E+005$ & 1 & $1.894 E+005$ & 32.33 & 0.0001 \\
\hline Residual & $70,302.09$ & 12 & 5858.51 & & \\
\hline Cor total & $2.388 \mathrm{E}+006$ & 31 & & & \\
\hline
\end{tabular}

$R^{2}$ 0.9706, Adj $R^{2}$ 0.9240, predicted $R^{2}$ 0.7907, CV 3.54\%, Adeq precision 24.085 $d f$ degree of freedom

Significant $P<0.05$, non-significant $P>0.05$

extract $(1 \% \mathrm{w} / \mathrm{w})$. In this manner, Fig. 3f illustrates that the response was enhanced at middle level of starch $(1 \% \mathrm{w} / \mathrm{w})$, and higher level of yeast extract concentration $(1 \% \mathrm{w} / \mathrm{w})$. The normality assumption $v_{\mathrm{s}}$ internally studentized residuals were found to be satisfactory due to the plot obtained in straight line (figure not shown).

\section{Model validation}

The validation of the statistical strategy was carried out under above mentioned optimized parameters selected through CCD. The amylase activity of about
$4572.53 \pm 40.21 \mathrm{U} / \mathrm{g}$ was estimated at the following medium constituents and culture condition valuesstarch $1 \%(\mathrm{w} / \mathrm{w})$, yeast extract $1 \%(\mathrm{w} / \mathrm{w})$, moisture $100 \%$, and incubation temperature $40{ }^{\circ} \mathrm{C}$. The observed dependent response was very much close to the predicted response value of $4467.95 \pm 40.61 \mathrm{U} / \mathrm{g}$, thereby indicating the validation of model towards enhanced amylase yield. Most importantly, the reasonable $R^{2}$ value illustrates the valid behaviour of the statistical strategy that can be implied for interpolation in the observational domain.

\section{Partial characterization of amylase}

The amylases obtained from strain ALA4 at statistically optimized conditions were further assessed for stability towards diversiform ranges of $\mathrm{pH}$ (Fig. 4a). The enzyme was found to be stable at a wide range of $\mathrm{pH}$ from 6.0 to 10.0 . The amylase showed stability up to $\mathrm{pH} 10.0$ for $4 \mathrm{~h}$ of incubation with $52.32 \%$ of residual activity, and reduced rapidly thereafter.

Figure $4 \mathrm{~b}$ depicts the stability of amylase at varied ranges of incubation temperature. The enzyme showed stability up to $65{ }^{\circ} \mathrm{C}$ for $4 \mathrm{~h}$ of incubation with $46.12 \%$ of residual activity, and reduced drastically thereafter. The amylases were found to be highly stable to the metal ions in the order of $\mathrm{Ca}^{2+}$ $>\mathrm{Mg}^{2+}>\mathrm{Mn}^{2+}>\mathrm{Cu}^{2+}>\mathrm{Fe}^{2+}>\mathrm{Zn}^{2+}>\mathrm{Co}^{2+}>\mathrm{Hg}^{2+}$ with residual activities of $98.32 \pm 3.3,96.12 \pm 3.3,92.24 \pm 3.3$, $66.15 \pm 2.3,60.04 \pm 2.4,58.12 \pm 3.2,52.13 \pm 2.3$, and $28.22 \pm 1.3 \%$, respectively (Fig. 4c).

\section{Eco-friendly applications}

The amylase of strain ALA4 was found to be promising in terms of resistivity towards various organic solvents studied (Fig. 5a). The study showed stability of enzyme in the presence of $n$-hexane, $n$-butanol, benzene, toluene, ethanol, methanol, ethyl acetate, chloroform, acetone, and propanol with residual activities of $73.16 \pm 3.3$, $68.13 \pm 3.3,36.12 \pm 1.3,67.14 \pm 3.2,91.16 \pm 2.3$, $84.12 \pm 2.4,80.14 \pm 3.3,70.13 \pm 2.1,78.15 \pm 3.3$, and $51.23 \pm 2.2 \%$, respectively.

The enzyme showed high tolerant characteristics in the presence of varied surfactants tested (Fig. 5b). Maximum

Table 4 Independent variables with their ranges and levels for CCD of RSM

\begin{tabular}{|c|c|c|c|c|c|c|}
\hline \multirow[t]{2}{*}{ Variables } & \multirow[t]{2}{*}{ Code } & \multicolumn{5}{|c|}{ Range and levels } \\
\hline & & $-a$ & -1 & 0 & +1 & $+a$ \\
\hline Temperature $\left({ }^{\circ} \mathrm{C}\right)$ & $A$ & 37 & 40 & 42 & 45 & 50 \\
\hline Moisture (\%) & B & 80 & 90 & 100 & 110 & 120 \\
\hline Starch (\%) & C & 0.3 & 0.5 & 1 & 1.5 & 2 \\
\hline Yeast extract (\%) & $D$ & 0.1 & 0.3 & 0.5 & 1 & 1.5 \\
\hline
\end{tabular}


Table 5 Experimental and predicted values of response through CCD

\begin{tabular}{|c|c|c|c|c|c|c|}
\hline \multirow[t]{2}{*}{ Run order } & \multirow[t]{2}{*}{ Temperature $(A)$} & \multirow[t]{2}{*}{ Moisture $(B)$} & \multirow[t]{2}{*}{ Starch $(C)$} & \multirow[t]{2}{*}{ Yeast extract $(D)$} & \multicolumn{2}{|c|}{ Amylase activity (U/g) } \\
\hline & & & & & Experimental & Predicted \\
\hline 1 & -1 & 1 & 1 & 1 & 4315.23 & 4438.18 \\
\hline 2 & 0 & 0 & 0 & 0 & 3742.12 & 3643.23 \\
\hline 3 & 0 & $+a$ & 0 & 0 & 3667.24 & 3578.68 \\
\hline 4 & 0 & 0 & $+a$ & 0 & 3541.12 & 3565.22 \\
\hline 5 & 1 & -1 & 1 & -1 & 3358.45 & 3453.53 \\
\hline 6 & -1 & 1 & -1 & 1 & 4116.34 & 4060.22 \\
\hline 7 & 0 & 0 & 0 & 0 & 3521.12 & 3643.23 \\
\hline 8 & 1 & 1 & 1 & 1 & 3321.12 & 3309.54 \\
\hline 9 & 1 & 1 & -1 & -1 & 3562.76 & 3694.06 \\
\hline 10 & -1 & -1 & -1 & 1 & 4176.46 & 4299.58 \\
\hline 11 & $-a$ & 0 & 0 & 0 & 3875.43 & 3864.88 \\
\hline 12 & -1 & 0 & 0 & 1 & 4572.53 & 4467.95 \\
\hline 13 & 0 & 0 & 0 & $-a$ & 3412.72 & 3271.65 \\
\hline 14 & 0 & 0 & 0 & 0 & 3678.16 & 3643.23 \\
\hline 15 & -1 & 1 & -1 & -1 & 3276.54 & 3354.31 \\
\hline 16 & $+a$ & 0 & 0 & 0 & 3554.53 & 3421.58 \\
\hline 17 & 0 & 0 & 0 & $+a$ & 3774.48 & 4014.81 \\
\hline 18 & 1 & 1 & 1 & -1 & 3528.65 & 3563.80 \\
\hline 19 & -1 & -1 & -1 & -1 & 3327.78 & 3302.17 \\
\hline 20 & -1 & 1 & 1 & -1 & 3317.56 & 3380.01 \\
\hline 21 & 1 & -1 & 1 & 1 & 3486.43 & 3490.78 \\
\hline 22 & 0 & 0 & $-a$ & 0 & 3663.43 & 3721.24 \\
\hline 23 & 0 & 0 & 0 & 0 & 3675.67 & 3643.23 \\
\hline 24 & 0 & 0 & 0 & 0 & 3781.45 & 3643.23 \\
\hline 25 & -1 & -1 & 1 & -1 & 2864.34 & 2924.15 \\
\hline 26 & 1 & -1 & -1 & -1 & 3952.18 & 3987.50 \\
\hline 27 & 1 & 1 & -1 & 1 & 3065.23 & 3087.54 \\
\hline 28 & 1 & -1 & -1 & 1 & 3772.13 & 3672.49 \\
\hline 29 & -1 & -1 & 1 & 1 & 4366.17 & 4273.83 \\
\hline 30 & 0 & $-a$ & 0 & 0 & 3654.27 & 3707.78 \\
\hline
\end{tabular}

residual activity of $96.17 \pm 3.3 \%$ was estimated for amylase in the presence of Tween 20, followed by Tween $40(92.12 \pm 2.3 \%)$, Tween 60 (90.14 $\pm 3.2 \%)$, Tween 80 $(82.12 \pm 2.3 \%)$, and SDS (52.16 $\pm 2.4 \%)$. Additionally the amylases showed remarkable resistance against inhibitors such as EDTA and mercaptoethanol with residual activities of $44.26 \pm 2.1 \%$ and $40.15 \pm 2.2 \%$, respectively. The stability of enzyme was reduced in the presence of hydrogen peroxide with the least residual activity of $14.12 \pm 1.1 \%$ (Fig. 5b).

Amylases obtained from strain ALA4 retained its maximum stability in the presence of detergents such as Tide $(90.13 \pm 2.3 \%)$ and ARIEL $(85.34 \pm 2.4 \%)$. A marginal reduction in the stability of amylase was obtained in the presence of detergents like surf excel, POWER, Wheel, Nirma, and RIN (Fig. 5c).

\section{Discussion}

In the present context, a hyperamylase producing bacterium was isolated from industrial waste soil sample. The isolate was identified as G. arilaitensis based on morphological, biochemical, and molecular characterization. This new isolate was further submitted to Genbank and identified as G. arilaitensis strain ALA4 with 99\% $16 \mathrm{~S}$ rRNA gene sequencing similarity report. $16 \mathrm{~S}$ rRNA gene sequences, due to the presence of highly conserved regions, are widely studied as the most common molecular marker to understand the phylogeny and taxonomy of any bacterium. In fact, these sequences describe the level and occurrence of phylogenetic relationships because of the presence of species-specific variable regions. This molecular technique has been extensively used for bacterial phylogeny, thereby leading to the establishment of 
Table 6 Analysis of variance (ANOVA) for amylase quadric model from strain ALA4

\begin{tabular}{|c|c|c|c|c|c|}
\hline Source & $\begin{array}{l}\text { Sum } \\
\text { of squares }\end{array}$ & $d f$ & Mean square & $F$ value & $\begin{array}{l}P \text { value } \\
\text { prob }>F\end{array}$ \\
\hline Model & $3.800 E+006$ & 10 & $3.800 E+005$ & 20.97 & $\begin{array}{c}<0.0001 \\
\text { signifi- } \\
\text { cant }\end{array}$ \\
\hline$A-A$ & $3.056 \mathrm{E}+005$ & 1 & $3.056 \mathrm{E}+005$ & 16.86 & 0.0006 \\
\hline$B-B$ & $24,998.28$ & 1 & $24,998.28$ & 1.38 & 0.2548 \\
\hline$C-C$ & $36,511.02$ & 1 & $36,511.02$ & 2.01 & 0.1720 \\
\hline$D-D$ & $8.587 E+005$ & 1 & $8.587 E+005$ & 47.38 & $<0.0001$ \\
\hline$A B$ & $1.194 \mathrm{E}+005$ & 1 & $1.194 E+005$ & 6.59 & 0.0189 \\
\hline$A C$ & $24,322.74$ & 1 & $24,322.74$ & 1.34 & 0.2611 \\
\hline$A D$ & $1.819 \mathrm{E}+006$ & 1 & $1.819 \mathrm{E}+006$ & 100.34 & $<0.0001$ \\
\hline$B C$ & $1.630 E+005$ & 1 & $1.630 E+005$ & 8.99 & 0.0074 \\
\hline$B D$ & $84,976.62$ & 1 & $84,976.62$ & 4.69 & 0.0433 \\
\hline$C D$ & $1.241 \mathrm{E}+005$ & 1 & $1.241 E+005$ & 6.85 & 0.0170 \\
\hline Residual & $3.444 \mathrm{E}+005$ & 19 & $18,125.43$ & & \\
\hline Lack of fit & $3.050 E+005$ & 15 & $20,331.18$ & 2.06 & $\begin{array}{l}0.2532 \text { not } \\
\text { signifi- } \\
\text { cant }\end{array}$ \\
\hline Pure error & $39,415.55$ & 4 & 9853.89 & & \\
\hline Cor total & $4.145 E+006$ & 29 & & & \\
\hline
\end{tabular}

$R^{2}$ 0.9169, Adj $R^{2} 0.8732$, Predicted $R^{2} 0.7946$, CV 3.67\%, Adeq precision 18.572 df degree of freedom

Significant $P<0.05$, non-significant $P>0.05$

large public-domain databases and its vast exploitation in the identification of bacteria (Khusro and Aarti 2015). The identification of bacterium using $16 \mathrm{~S}$ rRNA sequencing in the present investigation is consistent with other related current reports (Dash et al. 2015; Dey et al. 2016). In recent years, a special attention had been given to the production of amylases from novel strains of bacteria such as Halomonas meridian (Coronado et al. 2000), Rheinheimera aquimaris (Ghasemi et al. 2010), Bacillus barbaricus, Aeromonas veroni and Stenotrophomonas maltophilia (Kumar et al. 2014), and Chryseobacterium sp. (Hasan et al. 2017). In the line of those reports, we had undertaken a further significant attempt towards the amylolytic research, and isolated a new strain of $G$. arilaitensis with hyperamylase producing potentiality.

In last few decades, SSF has received great attention, and preferred to submerged fermentation $(\mathrm{SmF})$ for the production of industrially value-added products, especially amylase. The success of bioprocesses in SSF is linked to the suitability of various strains of bacteria, substrates, and process variables. The selection of appropriate substrates plays a pivotal role not only in the efficient and cost-effective production of enzymes but also the growth and development of bacteria. In the present investigation, among varied agro-residues used, goat dung was found to be an appropriate substrate for the growth of strain ALA4 under SSF, and revealed the maximum production of amylases from them. This might be because of the high moisture holding capability of goat dung in a comparison with other agro-residues. Moreover, goat dung may be utilized as promising substrate for the amylase production due to its easy availability nature, cost-effectiveness, and most importantly the presence of high nutrients $(\mathrm{g} / \mathrm{kg}$ : Soluble carbohydrate- 6.35 , Crude protein-9.6, Ash-85.8, C-250, N-26, P-4, K-46, Ca-7, $\mathrm{Mg}-12.1 ; \mathrm{mg} / \mathrm{kg}: \mathrm{Mn}-48, \mathrm{Fe}-73, \mathrm{Cu}-7.6$, and $\mathrm{Zn}-37$ ) with respect to other agro-residues (Mnkeni and Austin 2009). In addition to the above mentioned characteristics of goat dung as condign substrate for amylase productivity from strain ALA4, this inexpensive organic waste can be used not only to mitigate the environmental pollution but also achieve the strategy for cleaner society. Recently, few investigations had already reported the overwhelming yield of amylases from distinct bacterial sources using unique organic wastes viz. cassava bagasse (Ray and Kar 2009), cow dung (Vijayaraghavan et al. 2015), potato starchy wastes (Abd-Elhalem et al. 2015), and organic chicken wastes (Hasan et al. 2017). But study on the utilization of goat dung as feedstock for the successful production of amylase is not evidenced so far. Thus, the present study determined a versatile role of goat dung as inexpensive substrate for the production of amylolytic enzyme from G. arilaitensis strain ALA4.

The optimization of medium constituents and other abiotic factors are crucial to obtain high yield of amylases from specific bacterial sources. Cultivation period is one of the most important parameters that contribute a pivotal role in the productivity of enzymes. In the present context, strain ALA4 revealed maximum amylase activity at $48 \mathrm{~h}$ of incubation under SSF. The decline in the amylase yield thereafter might be due to the fact that strain ALA4 entered stationary phase, and produced high level of secondary metabolites in the medium due to the exhaustion of nutrients, thereby reducing the fermentation process. The time course study of OFAT approach was found to be in complete agreement with the report of Deb et al. (2013) who also demonstrated the maximum amylase yield from the isolate at $48 \mathrm{~h}$ of incubation period. In contrary to this, Nusrat and Rahman (2007) reported increased amylase yield up to $72 \mathrm{~h}$ of incubation. The finding of the present study proved to be an outstanding approach in terms of saving the necessity of energy for fermentation process and providing relatively an efficient handling.

According to the present study, strain ALA4 showed maximum amylase activity at $\mathrm{pH} 8$, and decreased significantly at lower and higher $\mathrm{pH}$ values. Similar observations were reported by Hasan et al. (2017) too. The 

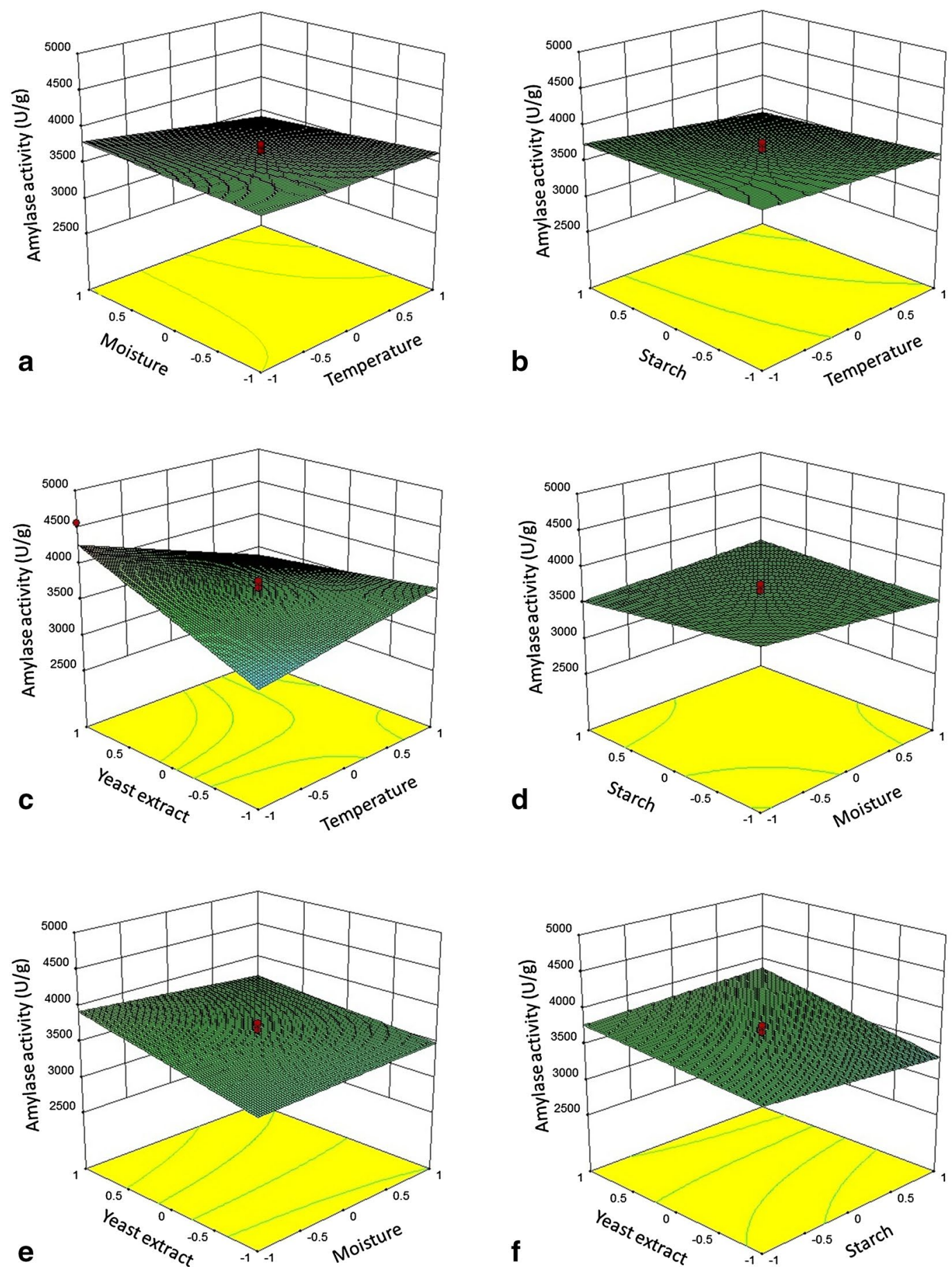

Fig. 3 Three dimensional response plot showing interaction between (a) temperature and moisture (b) temperature and starch (c) temperature and yeast extract (d) moisture and yeast extract $(\mathbf{e})$ moisture and yeast extract, and (f) starch and yeast extract

reduction in amylase activity after altering the $\mathrm{pH}$ of the culture medium might be due to the denaturation or inactivation of proteins. On the other hand, the optimum temperature for the increased amylase activity of strain
ALA4 was found to be $42{ }^{\circ} \mathrm{C}$. Further increment in the temperature showed reduction in the amylase activity, suggesting susceptibility of strain ALA4 at higher temperature. In fact, alteration in the incubation temperature 

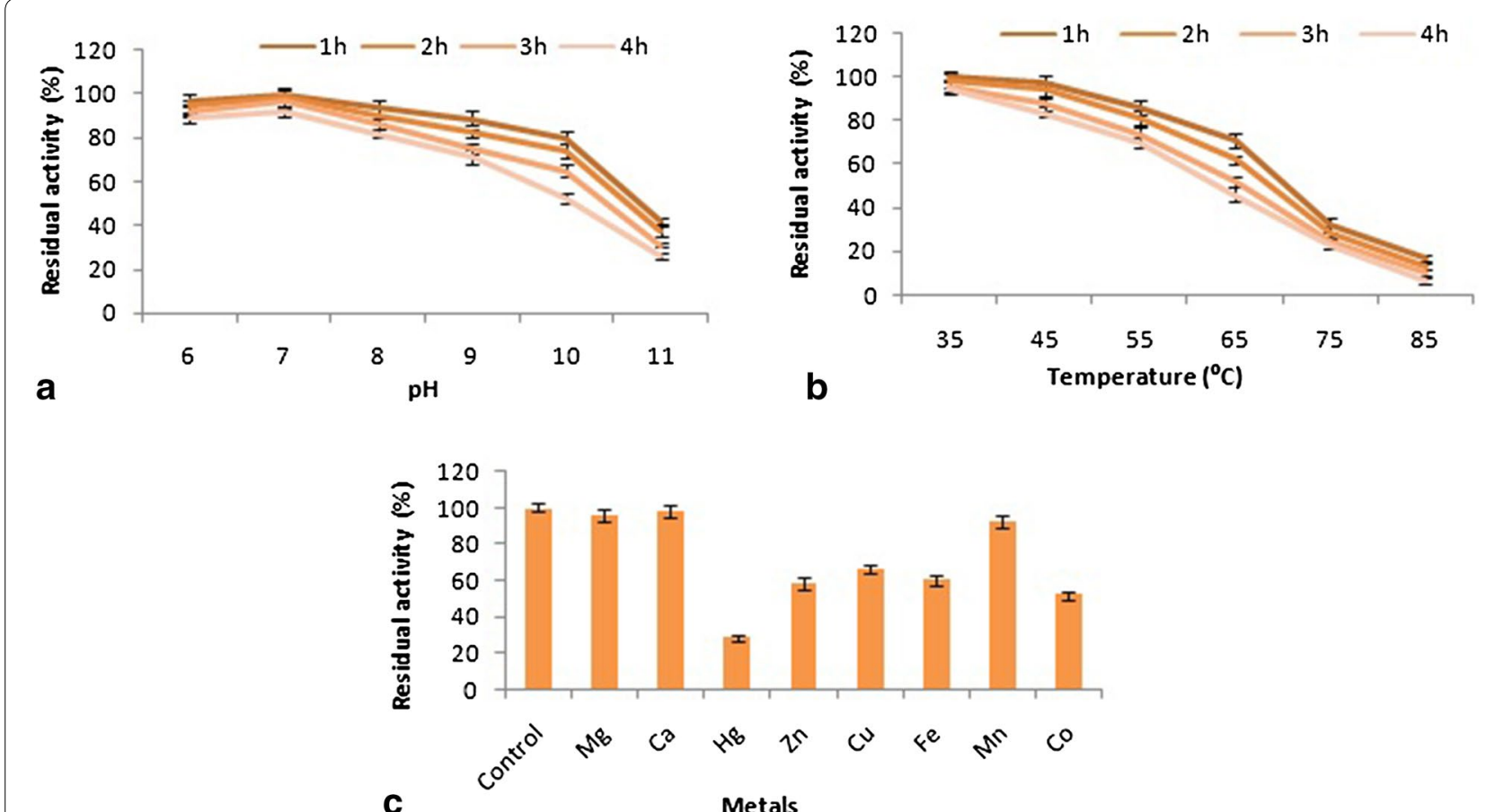

Fig. 4 Effect of a pH, b temperature, and $\mathbf{c}$ various metal ions on the stability of amylases. Values represent mean \pm SD

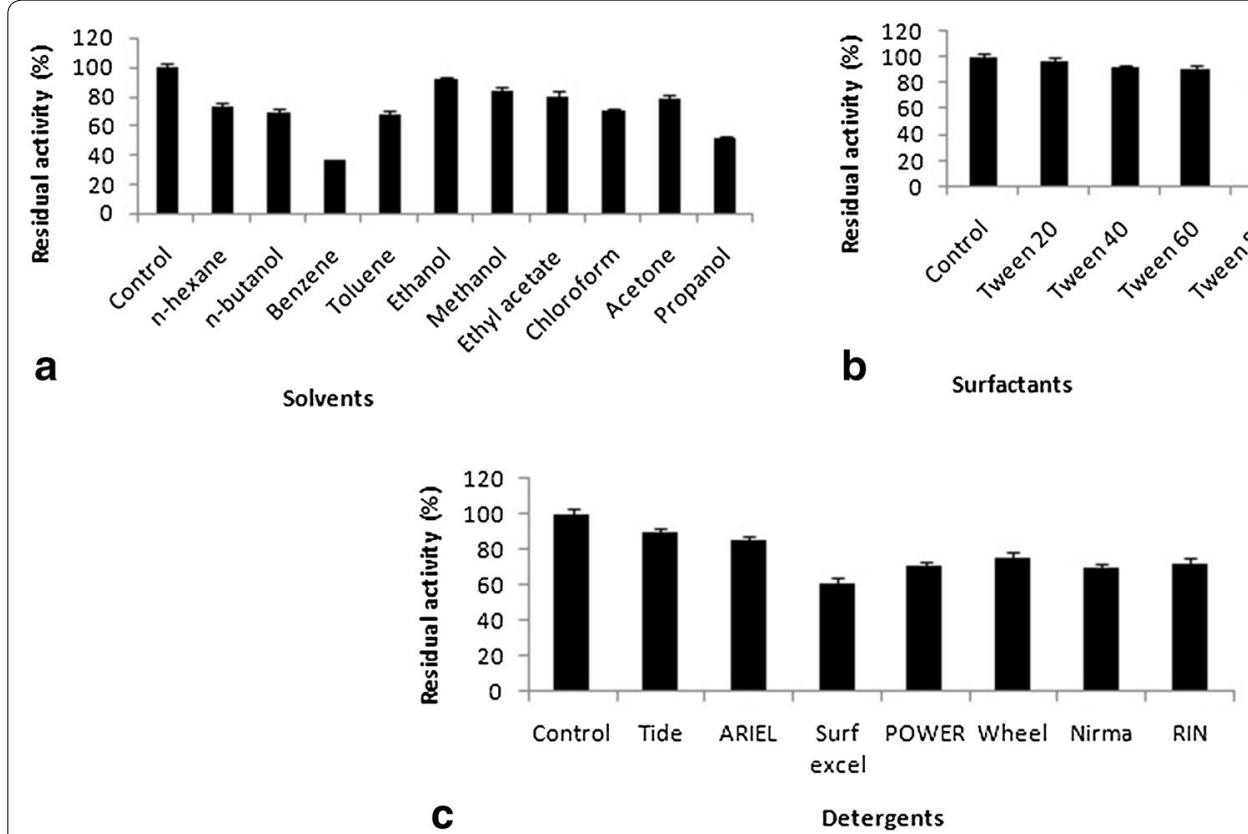

Fig. 5 Effect of various a organic solvents, $\mathbf{b}$ surfactants and inhibitors, and $\mathbf{c}$ commercially available detergents on the stability of amylases. Values represent mean \pm SD 
affects the bacterial biomass, thereby causing change in the amylase yield. In the line of our findings, Das et al. (2004) reported more or less similar results, demonstrating the temperature range of $35-45^{\circ} \mathrm{C}$ for the production of amylase by Bacillus sp. In the present investigation, the inoculum level had no influence towards the enhancement of amylase yield. The amylase activity was found to be decreased at higher inoculum level of strain ALA4. This might be due to the rapid growth of bacteria and rapid utilization of available nutrient sources in the initial stages. Similar observation was reported by Dash et al. (2015) as well. Moisture is one of the crucial parameters that strongly influence the enzyme yield from bacteria under SSF. In this context, strain ALA4 revealed maximum amylase activity at $100 \%$ moisture content. A significant reduction in the amylase activity of strain ALA4 was recorded at lower and above the optimum moisture content. This might be mainly due to the lower degree of goat dung swelling at low moisture content, thereby affecting amylase yield drastically. In general, the enzyme yield is influenced by the bacteria and substrate used under SSF (Prakasham et al. 2005).

Medium components such as carbon and nitrogen sources have profound impact on the amylase production from bacterial sources. In this study, strain ALA4 showed maximum amylase activity when the goat dung medium was supplemented with starch. It might be due to the fact that starch is metabolized slowly by the isolate as complex substrate with increasing accumulation of inducible amylase in the culture medium. The supplementation of other carbon sources revealed the reduced amylase yield under SSF. The utilization of soluble starch for the production of reasonable amount of extracellular amylase was previously reported by Tiwari et al. (2014) and Khusro and Aarti (2015). In contrary to this, Narang and Satyanarayana (2001), and Vijayaraghavan et al. (2015) demonstrated the increased amylase yield in the presence of lactose and fructose, respectively, from respective bacterial sources. In the present investigation, among eight nitrogen sources tested, yeast extract (organic nitrogen source) depicted the maximum yield of extracellular amylase. Similar observations were reported by Sharma et al. (2012) who demonstrated yeast extract as potent inducer of amylases from B. amyloliquefaciens. The availability of essential elements, coenzymes, nitrogenous constituents, and growth factors in yeast extract might be responsible for the amylase inducing property of the isolate. However, Hasan et al. (2017) revealed peptone as the most stimulatory nitrogen source for maximum production of amylases from both Chryseobacterium sp. and Bacillus sp.

Despite the wide applications of OFAT in bioprocess technology, this traditional method is a time-consuming approach and causes misinterpretation of data due to the large number of experiments to be performed. Most importantly, OFAT technique fails to illustrate the interdependent interaction between two factors. The statistical approaches are suitable alternatives to traditional methods of process optimization. In this regard, factorial experimental design such as two-level full factorial design matrix is one of the promising statistical tools that navigate the most influencing variables in enzyme bioprocess. In the present investigation, the amylase activity of strain ALA4 was enhanced using five variables at two different ranges ( $2^{5}$ full factorial design) in 32 experimental runs. Among five variables screened, incubation temperature, moisture content, starch, and yeast extract were observed to be the promising parameters that affect the response significantly $(P<0.05)$. These four factors were chosen further for the optimization studies using CCD with RSM. The CCD was carried out using four factors at five varied ranges. ANOVA results clearly demonstrate the influence of incubation temperature and yeast extract on enhanced amylase yield from strain ALA4 $(P<0.05)$. In the present context, extracellular amylase yield using CCD of RSM was observed to be increased about twofold in a comparison with OFAT method. A valid correlation between the experimental and predicted values of amylase activity was observed that verified the model, and established the existence of the optimal points. The $3 \mathrm{D}$ response graph shows the mutual interconnection between temperature, moisture, starch and yeast extract, and depicted that amylase activity was influenced significantly by incubation temperature and yeast extract concentration. In fact, RSM is a powerful statistical tool for optimizing diversified dependent and independent variables with minimum number of trials to enhance enzyme productivity. Thus, the study showed the successful implementation of statistical optimization to SSF that had eliminated the limitations of OFAT approach, and enhanced the amylase yield from strain ALA4 effectively.

The crude amylases obtained from strain ALA4 was evaluated for its stability at wide range of $\mathrm{pH}$. The enzyme was found stable up to $\mathrm{pH}$ 6.0-10.0 for $4 \mathrm{~h}$ of incubation, indicating one of the most important characteristics of this isolate. The finding of this study showed superiority to the previous reports of Aygan et al. (2008) and Vijayaraghavan et al. (2015) who demonstrated the stability of crude amylase up to $\mathrm{pH} 9.0$ and 8.0, respectively, from the respective isolates. The alkali-tolerant property of amylases from strain ALA4 for a longer period proved the isolate to be a potent source for varied biotechnological application, as suggested by Pal and Khanum (2010) too. In like manner, the crude amylase of strain ALA4 was observed to be highly stable up to $65^{\circ} \mathrm{C}$ for $4 \mathrm{~h}$ of incubation. The enzyme retained above $45 \%$ of residual activity 
after longer period of incubation. The finding of the present study strongly agrees with the report of Tiwari et al. (2014) who also observed sustainability of crude amylase from Bacillus sp. up to $65^{\circ} \mathrm{C}$. In contrary to our results, Dash et al. (2015) indicated the stability of amylase up to $50{ }^{\circ} \mathrm{C}$, and observed significant reduction thereafter. The long term temperature stability of amylases obtained from strain ALA4 would be crucial for several industrial applications. Out of eight different metal ions tested, the amylases obtained from strain ALA4 were found to be highly tolerant to all the metal ions except $\mathrm{Hg}^{2+}$. The amylase showed lower stability in terms of residual activity in the presence of $\mathrm{Hg}^{2+}$ ion. These observations were in accordance with the reports of Hernandez et al. (2006) who demonstrated the reduced stability of amylases in the presence of $\mathrm{Hg}^{2+}$. On the other hand, Tiwari et al. (2014) reported amylases from B. tequilensis with stability towards higher concentration of $\mathrm{Hg}^{2+}$.

The extraordinary resistant of amylase to various organic solvent revealed another crucial characteristic of strain ALA4. Similar study reporting the remarkable stability of amylase in the presence of hydrophilic and hydrophobic organic solvents was observed by $\mathrm{Li}$ and $\mathrm{Yu}$ (2012). The amylase was stable towards all the surfactants, and inhibitors such as EDTA and mercaptoethanol. In like manner, authors reported the existence of surfactant (Oberoi et al. 2001) and inhibitors tolerant amylases (Kikani and Singh 2011). The finding of the present study favoured the reports of Roohi et al. (2013) also who demonstrated reduction in the stability of enzyme in the presence of hydrogen peroxide. Bacterial amylases have several applications in detergent industry. Approximately $90 \%$ of commercially available detergents contain amylases (Mitidieri et al. 2006). Amylases are incorporated in the detergents to remove starchy food stains, such as chocolate, custard, gravy, etc. on clothes. In fact, the amylase in the detergent requires its compatibility and potentiality to perform in the presence of the detergents for inclusion. Very few studies have reported the identification of detergent stable amylases from bacterial sources. According to the present context, the amylase of strain ALA4 was stable towards commercially available detergents, thereby suggesting its suitability in the formulation of detergents. Similar finding was reported by Bajpai et al. (2015) with other bacterial species.

In view of the current demand of amylases in various industries, the amylase from strain ALA4 could be a potent substitute of chemical processes involved in starch hydrolysis. The amylases obtained from strain ALA4 could be used in the adverse industrial processes for its commercialization and thus, it could prove to be a better replacement of the existing enzymes on the market. The amylase activity of $G$. arilaitensis strain ALA4 achieved using $\mathrm{CCD}$ was found to be higher than most of the previous reports demonstrating the amylase yield from varied bacterial sources by utilizing various agroresidues (Table 7).

\section{Conclusions}

The present investigation evaluated the hyper-production of amylase from G. arilaitensis strain ALA4 using goat dung as an efficient substrate under SSF. The

Table 7 Comparative assessment of amylase production from various bacterial species by utilizing varied agro-residues

\begin{tabular}{|c|c|c|c|c|c|}
\hline Organism & Method & Carbon source & $\begin{array}{l}\text { Optimum pH and tem- } \\
\text { perature }\end{array}$ & Amylase activity & References \\
\hline Glutamicibacter arilaitensis & CCD & Goat dung & $\mathrm{pH} 8.0$; temperature $40^{\circ} \mathrm{C}$ & $4572.53 \mathrm{U} / \mathrm{g}$ & Present study \\
\hline Bacillus subtilis & Non-statistical & Banana peel & $\mathrm{pH} 7.0$; temperature $37^{\circ} \mathrm{C}$ & $331.37 \mathrm{U} / \mathrm{mL}$ & Sajjad and Choudhry (2012) \\
\hline Bacillus cereus & CCD & Cow dung & $\mathrm{pH} 8.0$; temperature $50^{\circ} \mathrm{C}$ & $464 \mathrm{U} / \mathrm{mL}$ & Vijayaraghavan et al. (2015) \\
\hline B. subtilis & CCD & Brewery waste & pH 6.6; temperature $36.8^{\circ} \mathrm{C}$ & $9.35 \mathrm{U} / \mathrm{mL}$ & Blanco et al. (2016) \\
\hline B. subtilis & Non-statistical & Rice flour & $\mathrm{pH} 8.0$; temperature $37^{\circ} \mathrm{C}$ & $9 \mathrm{U} / \mathrm{mL}$ & Dash et al. (2015) \\
\hline Bacillus brevis & CCD & Cassava bagasse & $\mathrm{pH} 7.0$; temperature $60^{\circ} \mathrm{C}$ & $4667 \mathrm{U} / \mathrm{mL}$ & Ray and Kar (2009) \\
\hline Bacillus amyloliquefaciens & Non-statistical & Potato starchy waste & $\mathrm{pH} 7.0$; temperature $50^{\circ} \mathrm{C}$ & $155.2 \mathrm{U} / \mathrm{mL}$ & Abd-Elhalem et al. (2015) \\
\hline B. amyloliquefaciens & CCD & Wheat bran & $\mathrm{pH} 8.0$; temperature $65^{\circ} \mathrm{C}$ & $63.12 \mathrm{U} / \mathrm{mL}$ & Prajapati et al. (2015) \\
\hline B. subtilis & Non-statistical & Wheat bran & $\mathrm{pH} 7.0$; temperature $42^{\circ} \mathrm{C}$ & $1918 \mathrm{U} / \mathrm{mL}$ & Maity et al. (2015) \\
\hline Anoxybacillus amylolyticus & Non-statistical & $\begin{array}{l}\text { Biomass of Cynara cardun- } \\
\text { culus }\end{array}$ & $\mathrm{pH} 5.6$; temperature $60^{\circ} \mathrm{C}$ & $102 \mathrm{U} / \mathrm{gds}$ & Finore et al. (2014) \\
\hline Bacillus sp. & Non-statistical & Wheat straw & $\mathrm{pH} 8.5$; temperature $45^{\circ} \mathrm{C}$ & 6900 U/g & Qureshi et al. (2016) \\
\hline Bacillus sp. & $\mathrm{BBD}$ & $\begin{array}{l}\text { Groundnut shell and cas- } \\
\text { sava waste }\end{array}$ & $\mathrm{pH} 7.0$; temperature $37^{\circ} \mathrm{C}$ & $866 \mathrm{U} / \mathrm{mL}$ & Selvam et al. (2016) \\
\hline Bacillus sp. & Non-statistical & Mustard Oil seed cake & $\mathrm{pH} 6.0$; temperature $50^{\circ} \mathrm{C}$ & $10666 \mathrm{U} / \mathrm{mL}$ & Saxena and Singh (2011) \\
\hline Paenibacillus amylolyticus & Non-statistical & Wheat bran & $\mathrm{pH} 8.0$; temperature $37^{\circ} \mathrm{C}$ & $275.95 \mathrm{U} / \mathrm{g}$ & Haq et al. (2012) \\
\hline
\end{tabular}


interdependent interaction among variables was investigated using CCD of RSM, and depicted about twofold amylase yield $(4572.53 \pm 41.71 \mathrm{U} / \mathrm{g})$ in a comparison with traditional method. The amylase productivity from strain ALA4 was significantly influenced by temperature and yeast extract concentration, thereby implying that enhanced yield of amylase can be obtained by maintaining the temperature, and adjusting the yeast extract concentration of the goat dung medium. Further, the amylases obtained were observed to be thermoalkali stable, and resistant to varied metal ions. Most importantly, the amylases of strain ALA4 were resistant to various organic solvents, surfactants, inhibitors, and commercially available detergents. The goat dung is proved to be an ideal inexpensive substrate in enzyme bioprocess and suggests its implementation in sustainable waste management practices in socially as well as economical manner.

\section{Authors' contributions}

CA and AK designed and carried out the experiments. CA and AK wrote the manuscript. PA verified the results and corrected the language of the manuscript. All authors read and approved the final manuscript.

\section{Acknowledgements}

Authors thank Maulana Azad National Fellowship (F1-17.1/2015-16/MANF2015-17-BIH-60730), University Grants Commission, Delhi, India for the partial support.

\section{Competing interests}

The authors declare that they have no competing interests.

\section{Availability of data and materials}

16S rRNA sequence and Accession number of isolate are available at GenBank (National Center for Biotechnology Information) database. Authors have agreed to provide the data and material for open access.

\section{Consent for publication}

Not applicable.

Ethics approval and consent to participate

Not applicable.

\section{Funding}

Not applicable.

\section{Publisher's Note}

Springer Nature remains neutral with regard to jurisdictional claims in published maps and institutional affiliations.

Received: 26 June 2017 Accepted: 26 September 2017

Published online: 04 October 2017

\section{References}

Abd-Elhalem BT, El-Sawy M, Gamal RF, Abou-Taleb KA (2015) Production of amylases from Bacillus amyloliquefaciens under submerged fermentation using some agro-industrial by-products. Ann Agric Sci 60:193-202

Awodun MA, Omonijo LI, Ojeniyi SO (2007) Effect of goat dung and NPK fertilizer on soil and leaf nutrient content, growth and yield of pepper. Int J Soil Sci 2:142-147
Aygan A, Arikan B, Korkmaz H, Dinçer S, Colak O (2008) Highly thermostable and alkaline a-amylase from a halotolerant-alkaliphilic Bacillus sp. AB68. Braz J Microbiol 39:547-553

Azad MAK, Bae JH, Kim JS, Lim JK, Song KS, Shin BS et al (2009) Isolation and characterization of a novel thermostable -amylase from Korean pine seeds. N Biotechnol 26:143-149

Bajpai B, Chaudhary M, Saxena J (2015) Production and characterization of a-amylase from an extremely halophilic archaeon, Haloferax sp. HA10. Food Technol Biotechnol 53:11-17

Blanco AS, Durive OP, Perez SB, Montes ZD, Guerra NP (2016) Simultaneous production of amylases and proteases by Bacillus subtilis in brewery wastes. Braz J Microbiol 47:665-674

Bradford MM (1976) A rapid and sensitive for the quantitation of microgram quantities of protein utilizing the principle of protein-dye binding. Analyt Biochem 72:248-254

Coronado M, Vargas C, Hofemeister J, Ventosa A, Nieto JJ (2000) Production and biochemical characterization of a-amylase from the moderate halophile Halomonas meridian. FEMS Microbiol Lett 183:67-71

Das K, Doley R, Mukherjee AK (2004) Purification and biochemical characterization of a thermostable, alkaliphilic, extracellular -amylase from Bacillus subtilis DM-03, a strain isolated from the traditional fermented food of India. Biotechnol Appl Biochem 40:291-298

Dash BK, Rahman MM, Sarker PK (2015) Molecular identification of a newly isolated Bacillus subtilis BI19 and optimization of production conditions for enhanced production of extracellular amylase. BioMed Res Int 2015:859805. doi:10.1155/2015/859805

Deb P, Talukdar SA, Mohsina K, Sarker PK, Abu Sayem SM (2013) Production and partial characterization of extracellular amylase enzyme from Bacillus amyloliquefaciens P-001. SpringerPlus 2:154

Dey U, Chatterjee S, Mondal NK (2016) Isolation and characterization of arsenic-resistant bacteria and possible application in bioremediation. Biotechnol Rep 10:1-7

Finore I, Donato PD, Poli A, Kirdar B, Kasavi C, Toksoy EO et al (2014) Use of agro waste biomass for a-amylase production by Anoxybacillus amylolyticus: purification and properties. J Microb Biochem Technol 6:320-326

Ghasemi Y, Rasoul-Amini S, Ebrahiminezhad A, Zarrini G, Kazemi A, MousaviKhorshidi S et al (2010) Halotolerant amylase production by a novel bacterial strain, Rheinheimera aquimaris. Res J Microbiol 5:144-149

Haq IU, Hameed U, Mahmood Z, Javed MM (2012) Solid state fermentation for the production of a-amylase by Paenibacillus amylolyticus. Pak J Bot 44:341-346

Hasan MM, Marzan LW, Hosna A, Al-Hakim Azad AK (2017) Optimization of some fermentation conditions for the production of extracellular amylases by using Chryseobacterium and Bacillus isolates from organic kitchen wastes. J Genet Eng Biotechnol. doi:10.1016/j.jgeb.2017.02.009

Hernandez MS, Rodriguez MR, Guerra NP, Roses RP (2006) Amylase production by Aspergillus niger in submerged cultivation on two wastes from food industries. J Food Eng 73:93-100

Khusro A, Aarti C (2015) Molecular identification of newly isolated Bacillus strains from poultry farm and optimization of process parameters for enhanced production of extracellular amylase using OFAT method. Res J Microbiol 10:393-420

Khusro A, Barathikannan K, Al-Dhabi NA, Arasu MV, Agastian P (2016) Statistical optimization of thermo-alkali stable xylanase production from Bacillus tequilensis strain ARMATI. Electron J Biotechnol 22:16-25

Khusro A, Barathikannan K, Aarti C, Agastian P (2017) Optimization of thermo-alkali stable amylase production and biomass yield from Bacillus sp. under submerged cultivation. Fermentation 3:7. doi:10.3390/ fermentation3010007

Kikani BA, Singh SP (2011) Single step purification and characterization of a thermostable and calcium independent a- amylase from Bacillus amyloliquefaciens TSWK1-1 isolated from Tulsi Shyam hot spring reservoir, Gujarat (India). Int J Biol Macromol 48:676-681

Kumar SS, Sangeeta R, Soumya S, Ranjan RP, Bidyut B, Pradee DM (2014) Characterizing novel thermophilic amylase producing bacteria from Taptapani hot spring, Odisha, India. Jundishapur J Microbiol 7:1-7

Li X, Yu HY (2012) Purification and characterization of novel organic-solvent tolerant $\beta$-amylase and serine protease from a newly isolated Salimicrobium halophilum strain LY20. FEMS Microbiol Lett 329:204-211 
Maity S, Mallik S, Basuthakur R, Gupta S (2015) Optimization of solid state fermentation conditions and characterization of thermostable a-amylase from Bacillus subtilis (ATCC 6633). J Bioprocess Biotech 5:1-7

Miller GL (1959) Use of dinitrosalicylic acid reagent for determination of reducing sugar. Anal Chem 31:426-428

Mitidieri S, Martinelli AHS, Schrank A, Vainstein MH (2006) Enzymatic detergent formulation containing amylase from Aspergillus niger: a comparative study with commercial detergent formulations. Bioresour Technol 97:1217-1224

Mnkeni PNS, Austin LM (2009) Fertilizer value of human manure from pilot urine-diversion toilets. Water SA 35:133-138

Narang S, Satyanarayana T (2001) Thermostable-amylase production by an extreme thermophile Bacillus thermooleovorans. Lett Appl Microbiol 32:31-35

Nusrat A, Rahman SR (2007) Comparative studies on the production of extracellular -amylase by three mesophilic Bacillus isolates. Bangladesh J Microbiol 24:129-132

Oberoi R, Beg QK, Puri S, Saxena RK, Gupta R (2001) Characterization and wash performance analysis of an SDS stable alkaline protease from a Bacillus sp. World J Microbiol Biotechnol 17:493-497

Pal A, Khanum F (2010) Production and extraction optimization of xylanase from Aspergillus niger DFR-5 through solid-state fermentation. Bioresour Technol 101:7563-7569

Prajapati VS, Trivedi UB, Patel KC (2015) A statistical approach for the production of thermostable and alklophilic a-amylase from Bacillus amyloliquefaciens KCP2 under solid-state fermentation. 3 Biotech 5:211-220

Prakasham RS, Rao CS, Sarma PN (2005) Green gram husk-an inexpensive substrate for alkaline protease production by Bacillus sp. in solid-state fermentation. Bioresour Technol 97:1449-1454

Qureshi AS, Khushk I, Ali CH, Chisti Y, Ahmad A, Majeed H (2016) Coproduction of protease and amylase by thermophilic Bacillus sp. BBXS-2 using open solid-state fermentation of lignocellulosic biomass. Biocatal Agric Biotechnol 8:146-151
Ray RC, Kar S (2009) Statistical optimization of a-amylase production by Bacillus brevis MTCC 7521 in solid-state fermentation using cassava bagasse. Biologia 64:864-870

Roohi Kuddus M, Saima S (2013) Cold-active detergent-stable extracellular a-amylase from Bacillus cereus GA6: biochemical characteristics and its perspectives in laundry detergent formulation. J Biochem Tech 4:636-644

Sajjad M, Choudhry S (2012) Effect of starch containing organic substrates on alpha amylase production in Bacillus strains. Afr J Microbiol Res 6:7285-7291

Saxena R, Singh R (2011) Amylase production by solid-state fermentation of agro-industrial wastes using Bacillus sp. Braz J Microbiol 42:1334-1342

Selvam K, Selvankumar T, Rajiniganth R, Srinivasan P, Sudhakar C, Senthilkumar B et al (2016) Enhanced production of amylase from Bacillus sp. using groundnut shell and cassava waste as a substrate under process optimization: waste to wealth approach. Biocatal Agri Biotechnol 7:250-256

Sharma N, Vamil R, Ahmad S, Agarwal R (2012) Effect of different carbon and nitrogen sources on a-amylase production from Bacillus amyloliquefaciens. Int J Pharm Sci Res 3:1161-1163

Smitha RB, Jisha VN, Sajith S, Benjamin S (2013) Dual production of amylase and $\delta$-endotoxin by Bacillus thuringiensis sub sp. kurstaki during biphasic fermentation. Microbiology 82:794-800

Tiwari S, Shukla N, Mishra P, Gaur R (2014) Enhanced production and characterization of a solvent stable amylase from solvent tolerant Bacillus tequilensis RG-01: thermostable and surfactant resistant. Sci World J. doi:10.1155/2014/972763

Vijayaraghavan P, Kalaiyarasi M, Vincent SGP (2015) Cow dung is an ideal fermentation medium for amylase production in solid-state fermentation by Bacillus cereus. J Genet Eng Biotechnol 13:111-117

Yazid NA, Barrena R, Komilis D, Sanchez A (2017) Solid-state fermentation as a novel paradigm for organic waste valorisation: a review. Sustainability 9:224. doi:10.3390/su9020224

\section{Submit your manuscript to a SpringerOpen ${ }^{\circ}$ journal and benefit from:}

- Convenient online submission

- Rigorous peer review

- Open access: articles freely available online

- High visibility within the field

- Retaining the copyright to your article

Submit your next manuscript at $\boldsymbol{\nabla}$ springeropen.com 